ANADOLU, J. of AARI

ISSN: 1300-0225 (Print)

E-ISSN: 2667-6087 (Online)

2019, 29 (2): 93-102

DOI:10.18615/anadolu.660253

\title{
Financial Benefit Analysis of Organic Farming of Fluted Pumpkin (Telfairia occidentalis Hook. F.): Evidence from Nigeria
}

\author{
Kate EMEGHA-OKONKWO ${ }^{1}$ (D) Felix Odemero ACHOJA ${ }^{2^{*}}$ \\ Daniel Chukwujioke OKEKE ${ }^{3}$ \\ ${ }^{I}$ Department of Agricultural Economics and Extension, NnamdiAzikiweUniversity, Awka/Nigeria. \\ ${ }^{2}$ Department of Agricultural Economics and Extension, Faculty of Agriculture, \\ Delta State University, Asaba Campus, P.M.B. 95074, Asaba/Nigeria. \\ ${ }^{3}$ Nwafor Orizu College of Education, Nsugbe-Anambra State/Nigeria. \\ ${ }^{1}$ http://orcid.org/0000-0002-7419-0543 $\quad{ }^{2}$ http://orcid.org/0000-0002-9705-4923 \\ ${ }^{3}$ http://orcid.org/0000-0002-9402-0656 \\ *Corresponding author (Sorumlu yazar): lixmero40@yahoo.com., achojafelix@gmail.com \\ Received (Geliş tarihi): 24.02.2019Ａccepted (Kabul tarihi): 09.09.2019
}

\begin{abstract}
Despite the global emphasis on organic farming and its importance, there is limited information on the financial benefits of organic production of fluted pumpkin in Nigeria. The study examines the financial benefits of organic farming of fluted pumpkin. Primary data collected in 2018 from randomly selected 60 organic pumpkin farmers were analysed with the aid of descriptive and inferential statistical tools. The result of the study shows that the net return to farmer was N188,450 for organic fluted pumpkin production per farmer per production cycle. The test of hypothesis shows that there is significant positive difference in the gap between costs incurred and farm income earned in organic fluted pumpkin production. Factor analysis indicated that cost of labor and transportation of materials were the major determinants of profitability of organic fluted pumpkin production. Further result shows that the most serious constraints in organic production of fluted pumpkin were inadequate finance and under developed transportation system. It was recommended that financial institutions including cooperative societies should make credit available to organic fluted pumpkin farmers at relatively low interest rate to boost organic fluted pumpkin production.
\end{abstract}

Keywords: Profitability, small scale, organic farming, technology, fluted pumpkin, Telfairia occidentalis Hook. F.

\section{INTRODUCTION}

Organic farming is the natural production of quality crops, vegetables, animals without hurting the environment and people. Organic farming is the use of rich natural fertilizer to maximize biological activities and maintain long-term soil health. Food produced under organic practices is more nutritious, safe and of high quality. Organicbased food offers improved food security and an array of other economic, environmental, health and social advantages (Worthington, 2001; Anonymous, 2008). Organic farming involves traditional knowledge, innovation and modern science to benefit the environment and promote a good quality of life for all involved (Anonymous, 2004). The aim of organic farming is to create integrated human, environmentally and economically viable agricultural system that relies on local or on-farm renewable resources; management of ecological and biological processes (Anonymous, 2008).

As it stands, Nigeria has not yet fully developed its potential with respect to organic farming. Nigeria is an agrarian nation with records of being the 
leading producer of some crops in the world. Its organic farming status is less than 10 years of practice and still at the formative stage. Nigeria has a record of organic-based farming of 154 ha in 2007 and 11,979 ha in 2010 (Anonymous, 2014). Few farmers and NGO's have embraced the practice of organic farming, currently selling organic lemon grass tea, turmeric and other produce in local markets. This is an indication of under-maximization of the premium financial benefits of organic farming. The financial benefits (profitability) of organic farming of fluted pumpkin could be the major driving force of the development of organic farming in Nigeria. Institutional drivers of organic farming include the Nigerian Organic Agriculture Network (NOAN) which is responsible for Standardization and Certification of organic products in Nigeria (Anonymous, 2014).

Fluted Pumpkin (Telfairia occidentalis) is a widely used vegetable and is consumed by millions of Nigerians. The output of fluted pumpkin has not been able to adequately satisfy its demand in Delta state, Nigeria. There is the need to improve the production system of fluted pumpkin through the application of organic farming techniques by the farmers.

It is a known fact that technology adoption has some degree of relationship with the socioeconomic characteristics of the farmer. The use of organic farming could have some relationship with farmer characteristics such as farm size, labour availability, attitude to risk and income level (Achoja, 2013).

One of the drivers of technology adoption is the expected income flow by way of profitability. Hence profit is the bottom line of investment in fluted pumpkin production decision among farmers. Cost and profitability in organic farming of fluted pumpkin has not received adequate research attention before now. This study was designed to close the information gap with respect to cost, return and profitability in organic farming of fluted pumpkin in Delta state, Nigeria.

Despite the high nutritional value of fluted pumpkin and its importance, there is limited information on the pattern of production and profitability. Organic technology is needed for increased output, is environmental friendly and relatively cheap. Hence the need to promote human welfare without hazards to the environment with healthy living to human life will be achieved through the use of organic technology by farmers. Fluted pumpkin production is one of the main farming activities in the study area. This is obvious from the fact that fluted pumpkin market holds daily in the area.

Despite the significance of organic production of fluted pumpkin, there is no study conducted so far to assess its profitability. Empirical information on the financial benefit will attract investors to organic farming of fluted pumpkin. Also, where serious constraints are identified and addressed, organic farming of fluted pumpkin could gain popularity and development. A comprehensive study on the profitability determinants and constraints to organic farming of fluted pumpkin is warranted for relevant policy framework for organic-based agricultural economy in Nigeria. The broad objective of the study was to analyze the financial benefits of organic farming of fluted pumpkin in Delta State, Nigeria.

\section{Objective of the Study}

The broad objective of the study was the financial analysis of organic farming of fluted pumpkin in Delta State, Nigeria.

The specific objectives are to:

i. Identify the socio economic characteristics of small scale organic fluted pumpkin farmers;

ii. Examine the cost analysis of organic farming of fluted pumpkin;

iii. Examine the net farm income in organic farming of fluted pumpkin;

iv. Determine the factors that affect the profitability of organic farming of fluted pumpkin;

v. Identify the constraints faced by organic fluted pumpkin farmers in a study area.

The following hypotheses were formulated and tested to guide the study.

$\mathrm{Ho}_{1}$ : There is no significant relationship between the profitability and selected socio-economic variables. 
$\mathrm{Ho}_{2}$ : Net farm income is not significantly different from to cost of organic farming.

\section{MATERIALS AND METHODS}

\section{Description of Study Area}

The study was carried out in Delta State, Nigeria in 2018. The area was chosen because pumpkin production is one of the common economic activities of the people. Delta state is made up of 25 local government areas with three agricultural zones namely: Delta North, Delta Central and Delta South. The state lies between longitude $5^{\circ} \mathrm{N}$ and $6^{0} 45^{\mathrm{I}} \mathrm{N}$ East and Latitude $5^{0}$ and $6^{0} 30^{\mathrm{I}}$ North. The average annual rainfall of about $2667 \mathrm{~mm}$ is recorded in the coastal areas and $1905 \mathrm{~mm}$ in the northern areas. The state has an average temperature range of about $29^{\circ} \mathrm{C}$ to $38^{\circ} \mathrm{C}$. Delta state has a total land areas estimated at 17.698 square kilometers that $1770 \mathrm{~km}^{2}$ is made up of fresh water swamp $5640 \mathrm{~km}^{2}$ of mangrove swamp and $10088 \mathrm{~km}$ of rain forest. The major economic activity of the people is farming. The crops grown include tree crops such as rubber, oil palm, tuber crops such as cassava, yam, cocoyam, cereals, such as maize, swamp rice and assorted vegetables. The livestock commonly reared include pigs, sheep, goat, poultry and fish both on small and large scale. The common agricultural problems of the area include inadequate land, poor soil, continuous cropping, inadequate finance, flooding, oil spillage and bush burning with devastating effects on agricultural development.

\section{Sampling Procedure and Sample Size}

A multistage sampling technique (Achoja, 2012) was adopted in the selection of location and organic fluted pumpkin farmers.

Firstly, two local government areas each were randomly selected from the three agricultural zones. They were Oshimili North, Isoko North, Ethiope west, Aniocha South, Ethiope East and Okpe.

In stage two, from each of the six local government areas selected, ten small scale fluted pumpkin farmers were selected. This gave the total of 60 fluted pumpkin farmers that were selected out of the 142 registered fluted pumpkin extension contact farmers of Delta state Agricultural
Development Project (ADP). This gave $42.25 \%$ of the population of registered fluted pumpkin farmers.

\section{Method of Data Collection}

The study employed primary data which were generated through the use of structured questionnaire. The instrument was subjected to reliability and validity tests (Achoja, 2019). The questionnaire was structured according to the specific objectives of the study. These included the socio-economic characteristics of respondents, cost of production, output data, revenue, profit and constraint in organic pumpkin production. Questionnaire copies were personally administered to respondents (small scale organic fluted pumpkin farmers) from June to July, 2018.

\section{Data Analytical Technique}

Descriptive statistics such as frequency distribution table, mean, percentage and standard deviation were used (Achoja, 2019) to describe the socioeconomic characteristics of small scale organic fluted pumpkin farmers.

The cost analysis of organic farming of fluted pumpkin was determined by cost function (Achoja, 2019).

Profit function was used to examine the net farm income (Achoja, 2012) in organic farming technology among fluted pumpkin farmers. Ordinary least square technique of multiple regressions was used (Achoja, 2012) to determine the factors affecting the profitability of organic farming of fluted pumpkin.

The constraints faced by organic fluted pumpkin farmers were identified with descriptive statistics (Achoja and Akporhuarho, 2016).

\section{Model Specification}

\section{MODEL 1}

Cost function (Achoja, 2019).

Cost function is specified as:

$\mathrm{Tc}=\Sigma \mathrm{X}_{\mathrm{i}} \mathrm{P}_{\mathrm{i}}+\mathrm{Fc}$

Where $T c=$ Total cost $X_{i} \cdot P_{i}$ expenditure on ith

Input..., $\mathrm{Fc}=$ fixed costs 


\section{MODEL 2}

Profit function (Achoja, 2019)

Profit function is specified as:

$\pi=T R-T C$

$\pi=Q \cdot P_{q}-\left[\Sigma\left(X_{i} P_{i}-F C\right)\right]$

Where

$\pi=$ Net profit

$\mathrm{TR}=$ Total Revenue

$\mathrm{TC}=$ Total cost

$\mathrm{Q}=$ Quantity of output

$\mathrm{P}_{\mathrm{q}}=$ Unit Price of Output

\section{MODEL 3}

Multiple regression model (Achoja, 2019).

The multiple regression models were implicitly specified as:

$Y=f\left(X_{1}, X_{2} \ldots \ldots \ldots X_{n} e\right)$

1. Linear form:

$y=b o+b_{1} X_{1}+b_{2} X_{2}+b_{3} X_{3}+\ldots \ldots b_{10} X_{10}+e$

2. Semi-Log Form:

$y=b o+b_{1} \log X_{1}+b_{2} \log X_{2}+b_{3} \log X_{3}+\ldots \ldots b_{10} X_{10}+e$

3. Double log form:

$\log y=b o+b_{1} \log X_{1}+b_{2} \log X_{2}+b_{3} \log X_{3}+\ldots b_{10} \log X_{10}+e$

4. Exponential form:

$\log y=b o+b_{1} X_{1}+b_{2} X_{2}+b_{3} X_{3}+\ldots b_{10} X_{I 0}+e$

$\mathrm{Y}$ is the dependant variable; $\mathrm{X}_{1}, \mathrm{X}_{2}, \mathrm{X}_{3}+\ldots \ldots \mathrm{X}_{10}$ are the independent or explanatory variables. The $b_{0}, b_{1}, b_{2}, b_{3} \ldots b_{10}$ are the regression co-efficient of parameters in the estimated equation.
The ordinary least square multiple regression technique was used to determine the factors affecting the profitability of organic farming of fluted pumpkin. The model symbols and a priori expectation signs are shown in Table 1.

\section{RESULTS and DISCUSSION}

\section{Socio-Economic Characteristics of Small Scale Fluted Pumpkin Organic Farmers in the Study Area}

The socio-economic characteristics of small scale fluted pumpkin farmers were discussed under the following: age, sex, marital status, educational level, years of farming experience, farm size and household size.

The result of the socio-economic characteristics of fluted pumpkin organic farmers is presented in Table 2.

The result of the age of small scale organic fluted pumpkin farmers in the study area are presented in Table 2.

The majority $(61.67 \%)$ of small scale organic fluted pumpkin farmers were within the age bracket of 31-50 years. The average age of fluted pumpkin farmers in the study area was 45.5 years. The age range shows economically productive age. Fluted pumpkin farmers developmental programme should be planned for this age bracket. This agrees with the findings of Nwajiuba (2012) who reported that the average age of farmers in the south east is 45 years.

The result shows that a moderate proportion $(60 \%)$ is female and a fairly good proportion $(40 \%)$ is male. It indicates that females are more involved in pumpkin production in the study area. This

Table 1. Description of variable symbols in multiple regression equation.

\begin{tabular}{clcc}
\hline Variable symbols & Variable description & Unit of measurement & Apriori expectation \\
\hline $\mathrm{Y}$ & Amount of profit & Naira & Positive \\
$\mathrm{X}_{1}$ & Labour cost & Naira & Negative \\
$\mathrm{X}_{2}$ & Cost of organic material & Naira & Negative \\
$\mathrm{X}_{3}$ & Cost of land & Naira & Negative \\
$\mathrm{X}_{4}$ & Unit price of output & Naira & Positive \\
$\mathrm{X}_{5}$ & Cost of planting material & Naira & Negative \\
$\mathrm{X}_{6}$ & Cost of transportation & Naira & Negative \\
$\mathrm{X}_{7}$ & Cost of communication & Naira & Negative \\
\hline $\mathrm{B}_{0}=$ Constant; $\mathrm{B}_{1}-\mathrm{B}_{7}=$ coefficient of parameter estimate; $\mathrm{e}=$ error term & \\
\hline
\end{tabular}


shows that the participation of women in fluted pumpkin production has increased tremendously. This agrees with the report of the study financed by the United Nations Development Programme (UNDP/UNCTAD) which revealed that women make up 60-80 percentage of agricultural labour force in Nigeria (Anonymous, 2008).

The results of small scale organic fluted pumpkin farmers by marital status in the study area are presented in Table 2. About 55\% of the organics fluted pumpkin farmers were married. They can settle down and coordinate their farm business. Married organic fluted pumpkin farmers have the benefit of family labor compared to the unmarried.

Table 2. Socio-economic characteristics of fluted pumpkin organic farmers (§).

\begin{tabular}{|c|c|c|}
\hline Variable & Frequency & $\begin{array}{c}\text { Percentage } \\
(\%)\end{array}$ \\
\hline \multicolumn{3}{|l|}{ Age (years) } \\
\hline 20 and below & 5 & 8.33 \\
\hline $21-30$ & 8 & 13.33 \\
\hline $31-40$ & 15 & 25.00 \\
\hline $41-50$ & 22 & 36.67 \\
\hline 61 and above & 10 & 16.67 \\
\hline \multicolumn{3}{|l|}{ Sex } \\
\hline Male & 24 & 40 \\
\hline Female & 36 & 60 \\
\hline \multicolumn{3}{|l|}{ Marital status } \\
\hline Never married & 18 & 30 \\
\hline Married & 33 & 55 \\
\hline Widow/widower & 6 & 10 \\
\hline Divorced & 3 & 5 \\
\hline \multicolumn{3}{|l|}{ Educational level } \\
\hline Noformal education & 15 & 25.00 \\
\hline Primary & 24 & 40.00 \\
\hline Secondary & 18 & 30.00 \\
\hline Tertiary & 3 & 5.00 \\
\hline \multicolumn{3}{|l|}{ Farm and below } \\
\hline 5 and below & 15 & 25.00 \\
\hline $6-10$ & 33 & 55.00 \\
\hline Above 10 & 12 & 20.00 \\
\hline \multicolumn{3}{|l|}{ Household size } \\
\hline Less than 3 & 9 & 15.00 \\
\hline $3-5$ & 12 & 20.00 \\
\hline $6-8$ & 30 & 50.00 \\
\hline 9 and above & 9 & 15.00 \\
\hline \multicolumn{3}{|l|}{ Years of experience } \\
\hline Below 7 & 6 & 10 \\
\hline $7-9$ & 12 & 20 \\
\hline $10-12$ & 27 & 45 \\
\hline 13 and above & 15 & 25 \\
\hline
\end{tabular}

\section{Hypothesis Testing}

Hol: Farm income is not significantly higher than cost of organic farming of pumkin.

The hypotheses was tested to find out whether or not farm income obtained by organic fluted pumpkin farmers is significantly higher than cost incurred. The result of hypothesis testing shows that calculated t-statistics values is 2.576 and critical T-value is 1.96. This shows that there is significant positive difference between costs incurred and farm income earned by organic fluted pumpkin farmers in the study area $(\mathrm{P}>0.05)$. For this result the null hypothesis is rejected and the alternative accepted. The net farm income earned derived from organic fluted pumpkin farming is statistically significant and can be generalized as a profitable business activity in the study area.

\section{Cost Analysis of Organic Farming of Fluted Pumpkin}

The result of cost analysis of organic farming of fluted pumpkin is shown in Table 3. The result of the cost analysis of organic farming of fluted pumpkin shows that the total variable cost was $\mathrm{N} 132,550$. The result shows that planting material (seeds) was $\$ 30$ per unit price with total of 210 seeds planted per farmer per production cycle at $4.75 \%$ of total variable cost. The cost of organic material takes about $51.10 \%$ of the total variable cost (TVC) followed by hired labour $(21.12 \%)$. Hence organic material was the major total variable cost item in organic fluted pumpkin production in the study area. 


\section{Results of Net Farm Income in Organic Family Technology among Fluted Pumpkin Farmers in the Study Area}

Table 3 presents the net farm income in organic farm technology among fluted pumpkin farmers in the study area.

The result of the net farm income of organic farming of fluted pumpkin is shown in Table 3 . The result of the net farm income of fluted pumpkin farmer per farmer per production cycle shows that the return on the investment was $110.6 \%$ (Table 3). The result shows that the total revenue for pod was $\mathrm{N} 280,000$. The result also shows that 41 bunches of pumpkin leaves were harvested and were sold by the farmer and the selling price per bunch was N1000.00.

The total revenue for pod and leaves was N321,000. The Gross margin was determined using the value of the difference between Total Revenue and Total Variable Cost.

The net farm income was N188,450 per farmer per production cycle (Table 3 ). About $87.29 \%$ of the net farm income goes to pod output, while $12.77 \%$ of net revenue was derived from pumpkin leaves output. This result indicates that fluted pumpkin pod generate more revenue than its leaves in the study area. While the sales of pod is usually hard at the end of the farming season, the pumpkin leaves are harvested and sold almost on every market day to generate regular income to the farmer. This finding agrees with the earlier reports of Halberg (2006) and Twarog (2006), concluded that organic farming, though labours intensive, and is profitable and valuable than conventional farming.

Table 3. Fluted pumpkin organic farming enterprise budget (per farmer per production cycle) (§).

\begin{tabular}{|c|c|c|c|c|c|}
\hline $\mathrm{S} / \mathrm{N}$ & Items & Quantity & $\begin{array}{l}\text { Unit Price } \\
\text { Cost (\#) }\end{array}$ & Amount & $\begin{array}{c}\text { Percentage } \\
\%\end{array}$ \\
\hline & Variable cost & & & & \\
\hline i. & Planting material (seeds) & 210 & 30 & 6,300 & 4.75 \\
\hline ii. & Organic material & 35 bags & 1,950 & 68,250 & 51.52 \\
\hline iii. & Hired labour & & & 28,000 & 21.12 \\
\hline iv. & Irrigation & & & 12,500 & 9.43 \\
\hline $\mathrm{v}$. & Transportation & & & 15,400 & 11.62 \\
\hline \multirow[t]{3}{*}{ vi. } & Communication & & & 2,100 & 1.58 \\
\hline & Total Variable Cost & & & 132,550 & \\
\hline & Fixed cost depreciation & & & & \\
\hline i. & Land (lease) & & & 13,000 & \\
\hline ii. & Wheel barrow & 1 & 5800 & 5,800 & \\
\hline iii. & Watering can & 2 & 2100 & 4,200 & \\
\hline iv. & Cutlass & 2 & 1800 & 3,600 & \\
\hline $\mathrm{v}$. & Hoe & 3 & 1100 & 3,300 & \\
\hline vi. & Shovel & 3 & 2100 & 6,300 & \\
\hline vii. & Basket & 8 & 200 & 1,600 & \\
\hline \multirow[t]{9}{*}{ viii. } & Building & & & 86,500 & \\
\hline & Total Fixed Cost & & & 37,800 & \\
\hline & Total Cost & & & 170,350 & \\
\hline & Revenue & & & & \\
\hline & Pod & 140 & 2000 & 280,000 & \\
\hline & Leaves & & & 41,000 & \\
\hline & Total revenue & & & 321,000 & \\
\hline & Gross margin of fluted pumpkin & & & 188,450 & \\
\hline & Return on investment (fluted pumpkin) & $110.6 \%$ & & & \\
\hline
\end{tabular}




\section{The Factors Affecting the Profitability of Organic Farming of Fluted Pumpkin in the Study Area}

The result of ordinary least square multiple regression analysis on factors affecting the profitability of organic farming of fluted pumpkin in the study area is shown in the Table 4.

The exponential function of the multiple regressions was accepted as the lead model on the basis of the value of $\mathrm{R}^{2}$ and the number of significant variables in the model.

The values of $\mathrm{R}^{2}$ and $\mathrm{F}$ - ratio are $0.721(72 \%)$ and 5.702 respectively. This indicates that approximately $72 \%$ of the variation in the dependent variable (profitability of organic farming), was due to socio-economic variables captured in the model. The values of the $\mathrm{R}^{2}$ and F-ratio thus provide reliable measures of the overall explanatory power of the regression model.

Ho2: There is no significant relationship between the profitability and selected socio-economic variables

At this point the results of the statistical significance of the individual explanatory variable in the model are discussed as follows:

\section{Cost of labour}

The cost of labour used has a negative relationship with profitability of fluted pumpkin. It is statistically significant in the model at 5\%. This result suggests that higher cost of labour in fluted pumpkin production can translate to higher total cost of production and reduced profitability. The higher the cost of labour in organic farming of fluted pumpkin, the lower the profit and the lower the cost of labour the higher the profit earned by organic fluted pumpkin farmers.

\section{Cost of organic material}

The result of the study shows that the cost of organic material has a negative relationship to profitability of fluted pumpkin in Delta State, Nigeria. Cost of organic material is significant at $1 \%$ probability level to profit. The coefficient of this variable is negative in conformity with a prior expectation that the higher the cost of organic material the lower the profit. This result indicates that higher cost of organic materials could increase total cost of organic farming of fluted pumpkin thereby reducing net farm income of the farmer.

Table 4. Distribution of socio-economic variables that determine the profitability of organic farming of fluted pumpkin (§).

\begin{tabular}{|c|c|c|c|c|c|c|c|c|}
\hline Variable & Linear & & Double lo & g & Semi log & & Exponentia & \\
\hline Constant & $\begin{array}{r}305473.01 \\
(2.001)\end{array}$ & $*$ & $\begin{array}{r}4.801 \\
(2.101)\end{array}$ & $*$ & $\begin{array}{r}-665272.200 \\
(-2.021)\end{array}$ & $*$ & $\begin{array}{r}13.148 \\
(21.511)\end{array}$ & \\
\hline Cost of labour & $\begin{array}{l}-32.005 \\
(-0.220)\end{array}$ & & $\begin{array}{r}220.394 \\
(0.213)\end{array}$ & & $\begin{array}{r}3.005 \\
(0.143)\end{array}$ & & $\begin{array}{r}3.0007 \\
(1.907)\end{array}$ & $* *$ \\
\hline Cost of organic material & $\begin{array}{r}-224.540 \\
(-0.834)\end{array}$ & & $\begin{array}{r}0.734 \\
(4.312)\end{array}$ & $* * *$ & $\begin{array}{r}-5230.22 \\
(0.123)\end{array}$ & & $\begin{array}{r}1.422 \\
(8.220)\end{array}$ & $* * *$ \\
\hline Cost of land & $\begin{array}{r}-1813.024 \\
(-0.421)\end{array}$ & & $\begin{array}{c}-0.2193 \\
(0.2341)\end{array}$ & & $\begin{array}{r}32.4021 \\
(0.442)\end{array}$ & & $\begin{array}{l}3.0257 \\
(1.983)\end{array}$ & $* * *$ \\
\hline Unit price of output & $\begin{array}{r}-123.40 \\
(-1.2007)\end{array}$ & & $\begin{array}{r}0.348 \\
(0.310)\end{array}$ & & $\begin{array}{r}-2340.10 \\
(-0.124)\end{array}$ & & $\begin{array}{r}1.345 \\
(6.434)\end{array}$ & $* * *$ \\
\hline Cost of planting material & $\begin{array}{r}-2872.00 \\
(14.002)\end{array}$ & $* * *$ & $\begin{array}{r}0.037 \\
(0.314)\end{array}$ & & $\begin{array}{r}-2.434 \\
(0.234)\end{array}$ & & $\begin{array}{r}-1.6780 \\
(2.035)\end{array}$ & $* *$ \\
\hline Transportation to organic material store & $\begin{array}{r}-25.200 \\
(0.2500)\end{array}$ & & $\begin{array}{r}0.341 \\
(-0.33)\end{array}$ & & $\begin{array}{r}0.2451 \\
(-0412)\end{array}$ & & $\begin{array}{r}32.451 \\
(-3.241)\end{array}$ & $* * *$ \\
\hline Cost of communication & $\begin{array}{r}-121.445 \\
(0.225)\end{array}$ & & $\begin{array}{r}-3001.21 \\
(0.301)\end{array}$ & & $\begin{array}{r}0.923 \\
(-1.234)\end{array}$ & & $\begin{array}{c}0.0132 \\
(2.320)\end{array}$ & $* *$ \\
\hline $\begin{array}{l}\mathrm{R}^{2} \\
\text { F-Ratio }\end{array}$ & $\begin{array}{l}0.563 \\
6.620\end{array}$ & $* *$ & $\begin{array}{l}0.421 \\
6.768\end{array}$ & $* *$ & $\begin{array}{l}0.311 \\
6.550\end{array}$ & $* *$ & $\begin{array}{l}0.712 \\
5.702\end{array}$ & $* *$ \\
\hline
\end{tabular}

$\S$ : Source: Computed data from field survey (2018); *= Significant at $10 \%$ level of probability; **= Significant at $5 \%$ level of probability; $* * *=$ Significant at $1 \%$ level of probability. 


\section{Cost of land}

The coefficient of this variable is negative in the model with the prior expectation that land increase will improve profitability. This may result that increase in size of land will lead to high cost, which could reduce profitability. Increase in cost of land (lease) could lead to use of little portion by small scale fluted pumpkin farmers, thereby affecting the level of profitability.

\section{Unit price of output}

The result of the study shows that unit price of output has a positive and significant relationship $(\mathrm{P}<0.01)$ with profitability. This may suggest that profitability of organic fluted pumpkin depends strongly on the ruling price of output. This finding indicates that the higher the unit price of output, the higher the profitability.

\section{Cost of planting material}

The result of the study shows that the cost of planting material posted a negative coefficient and significant at $5 \%$ probability level. Given that if the cost of planting material is high it could make the farmer to plant a small quantity which could result to low yield and as well low profit.

\section{Cost of transportation to organic material store}

Cost of transportation recorded a negative coefficient to profitability in the model, significant at $1 \%$ probability level. It shows that the cost of transportation could reduce the level of expected profit. Transportation cost to organic material store was selected as a proxy for profitability level in the study area. The negative sign implies that a high transportation cost would reduce the quantity of organic material small scale fluted pumpkin farmer would purchase and use for profitability. Therefore better rural road network would encourage low cost of transportation to organic material store and improved profit of small scale farmers. Oji (1997) earlier reported that a better market access would result a reduced transportation cost to fluted pumpkin farmers.

\section{Cost of communication}

The coefficient of cost of communication, is negative in the model in line with a prior expectation that communication network will promote the availability of organic material and improve profitability. Cost of communication is significant at 5\% probability level.

\section{Constraints Faced by Organic Fluted Pumpkin Farmers in the Study Area}

Table 5 presents the distribution of constraints faced by organic fluted pumpkin farmers in the study area.

Distribution of constraints faced by organic fluted pumpkin farmers in the study area is shown in Table 5. The constraints are discussed under the following heading: Majority (91.65\%) of small scale organic fluted pumpkin farmers agreed that inadequate finance was a problem in this production. This is in line with the prior findings of Alabi and Osifo (2004) earlier reported in their study that one of the major problem facing production and profit is lack of capital.

Table 5. Constraints of organic fluted pumpkin farming in the study area (§).

\begin{tabular}{lccc}
\hline Constraints & Frequency & Percentage $(\%)$ & Rank \\
\hline Inadequate finance & 55 & 91.65 & $1^{\text {st }}$ \\
Poor transportation & 51 & 85.00 & $2^{\text {nd }}$ \\
Lack of awareness & 50 & 83.33 & $3^{\text {rd }}$ \\
Market problem (produce) & 42 & 70.00 & $4^{\text {th }}$ \\
Shortage of organic material & 40 & 66.67 & $5^{\text {th }}$ \\
Low profit margin & 21 & 35.00 & $6^{\text {th }}$ \\
\hline Total & 60 & & \\
\hline
\end{tabular}

§: Source from field survey 2018 (Multiple Responses were recorded). 


\section{Poor transportation system}

Majority $(85 \%)$ of small scale organic fluted pumpkin farmers indicated that poor transportation system was a problem in the study area. This could be as a result of poor road network, high cost of transportation, high cost of petroleum products. These findings agrees with Paolo et al. (2008) reported that pattern of transportation are not encouraging to bring high profit.

\section{Post-harvest spoilage}

About $(75 \%)$ of the organic fluted pumpkin farmers agreed that postharvest spoilage was their major problem in the study area. This could be as a result poor storage facilities, delay in covey of produce to market and lack of patronage. As a result, organic fluted pumpkin farmers sell their produce at give-away prices thereby negatively affecting their profitability.

\section{Lack of awareness on the use of organic materials}

The result showed that $(83.33 \%)$ of small scale organic fluted pumpkin farmers agreed that lack of awareness of the use of organic material for farming was their major problem. So many farmers are yet to know the use an application of organic technology.

\section{Inadequacy of organic material}

About $(66.67 \%)$ of small scale organic fluted pumpkin farmers identified inadequacy of organic material as the major problem affecting their profitability. The result shows that lack of adequate proportion of organic material leads to poor yield, thereby reducing the profit of the farmers.

\section{Willingness to pay for organic material}

About (70\%) of respondents agreed that willingness to pay for organic material was one of their serious constraints. Fluted pumpkin is not sold at the same rate whether produced with organic material or not. This result contrast with what is obtainable in developed economics where consumers willing to pay a specific price for organic products. This implies that fluted pumpkin does not have a uniform price. This result agrees with Rao and Kiran (2013) who reported that prices of commodities defers as a constraint to fluted pumpkin marketing.

\section{Low profit margin}

The study shows that $35 \%$ of the small scale organic fluted pumpkin farmers perceived low profit margin as a constraint to profitability in organic farming technology. Profit is the aim and incentive for performing business activities. Low profit margin could strongly discourage current and potential producers of organic fluted pumpkin.

\section{SUMMARY and CONCLUDING REMARKS}

Profitability in organic farming technology among small scale fluted pumpkin farmers was investigated in this study. The result shows that there is substantial financial reward in organic fluted pumpkin production. The Gross Margin earned by organic fluted pumpkin farmers was enough to encourage current and potential investors in organic farming of fluted pumpkin in Nigeria. The findings of this study would be useful to investors in the organic pumpkin production business by identifying problem areas, prospects and potential areas of improvement. It is also expected that the study has provided an analytical framework for those currently engaged in the business on how to determine the actual level of their profitability and financial performance. It will assist banks, particularly credit managers in determining the credit worthiness of producers of organic fluted pumpkin before extending loans to them. Similarly, the study will prove invaluable to the government as a basis for rational and empirical policy formulation for organic farming of fluted pumpkin. The finding of this study has deepened our understanding on organic farming of fluted pumpkin in Nigeria. However, due to limited research resources, this study was limited to the financial benefits of organic farming of fluted pumpkin. It is important that researchers should identify related crop specific enterprises for further investigation on the financial benefits of organic agriculture in Nigeria and other nations. 
It was therefore recommended that:

1. Organic material should be made more available at relatively low cost.

2. The market price of fluted pumpkin pod and leaves should be encouraging to motivate organic fluted pumpkin farmers.

3. Since the return on pod is the major determinant of profitability, farmers should pay serious

\section{REFERENCES}

Achoja, F. O. 2012. Financial risk programming, volatility forecasting and management strategies in broiler enterprise in Delta state, Nigeria, Ph.D. Thesis (Unpublished) Department of Agricultural Economics and Extension, Delta state University, Abraka, Nigeria.

Achoja, F. O. 2013. Financial risk threshold determination in broiler enterprise in Delta State in Nigeria, Agricultural Tropica ET Subtropica 46 (14): 111-117.

Achoja, F. O. 2019. Analysis of profitability of shrimp value chain in Delta State, Nigeria. Ege Journal of Fisheries and Aquatic Sciences 36 (2): 125-133.

Achoja, F. O., and P. O. Akporhuarho. 2016. Profitability and constraints in the marketing of poultry birds in Delta Central Agricultural Zone of Delta State, Nigeria, Journal of Agriculture and Food Sciences 14 (1): 16-23.

Alabi, R., and R. A. Osito. 2004. Constraint to self-sufficiency in backyard poultry production in Edo State, Nigeria, Proceeding of the $9^{\text {th }}$ Annual conference of the Animal science association of Nigerians, pp. 177-180.

Anonymous. 2004. IFOAM. Network building for lobbying in Africa compiled by souleymane Bassoum, Rene Tokannou and Ngujimutura. Bonn: IFOAM.

Anonymous. 2008. United Nations Conference on Trade and Development (UNCTAD). Organic Agriculture and Food Security-Africa. United Nations Environment Programme (UNEP) UNCTAD Capacity Building TaskForce on Trade, Environment and Development, UN, New York and Geneva, p. 47. attention to pod production to enhance more profit.

4. Organic fluted pumpkin farmers should form cooperative societies to make credit available to themselves at relatively low interest rate. This will boost organic fluted pumpkin production in Delta state, Nigeria.

Anonymous. 2014. Report. USDA Foreign Agricultural Services. Organic Agriculture in Nigeria, Global Agricultural Information Network (GAIN).

Halberg, N. 2006. Global Development of Organic Agriculture: Challenges and Prospect. CABI p. 297.

Nwajiuba, C. 2012. Nigeria's Food Security Challenges. www.nestinterative.org, accessed: 11/25/2013.

Oji, K. O. 1997. Trends in Agricultural intensification under population pressure among small holder farmers in Imo and Abia State of South East Nigeria, Ph.D. Thesis, University of Nsukka.

Paolo, P., J. E. N. Asimiku, and W. Emeka-Okolie. 2008. Assessment of the Nigeria poultry market chain to improve bio security, food and agriculture organization of united nation Rome.

Rao, K. A., and K. Kiran. 2013. Expansion of micro insurance into low income groups J.of Research in Commerce \& Management 2 (9): 19-26.

Twarog, S. 2006. Organic Agriculture: A trade and sustainable development opportunity for developing countries, United Nations Conference on Trade and Development.

Worthington, V. 2001 Nutritional Quality of Organic Versus Conventional Fruits, Vegetable and Grains. The J. of Alternative and Complementary Medicine 7 (2): 161173.DOI: 10.1089/107555301750164244. 